\title{
Physiological Growth of Sunflower with Treatment of Zinc
}

\author{
Muhammad Imran Anwar", Saba Batool, Abdul Wadood Nadeem, Hajra Tabbasam, Sadia Batool, Shehnaz kousar
}

Department of Botany, University of Agriculture, Faisalabad, Pakistan

DOI: $10.36348 / \mathrm{sijb} .2020 . v 03 \mathrm{i} 08.003$

| Received: 27.07.2020 | Accepted: 04.08.2020 | Published: 14.08.2020

*Corresponding author: Muhammad Imran Anwar

\section{Abstract}

Metal ion contamination in the environment causes hazardous effects on plant growth, yield production, and also led to physical and chemical changes. Sunflower(Helianthus annus L.) plant is added to be one of the most edible seed crop growing in harsh climatic regions.it also have good water use efficiency. The study remains unclear about the physiological growth of sunflower with treatment of Zinc. A pot experiment was conducted in the old Botanical Garden at University of Agriculture, Faisalabad to analyze and check the impact of heavy metal zinc sulphat stress on sunflower (Heliantuus annuus) two hybrids FH687 and FH674. After three weeks varying concentration of zinc sulphate (0mM, $20 \mathrm{mM}$ and $40 \mathrm{mM}$ ) along with $250 \mathrm{ml}$ tap water was applied in rooting medium. Every day $250 \mathrm{ml}$ water were applied to each pots. The crop was harvested after 45 days and morphological parameters were studied such as root length, shoot length, root weight, shoot weight and number of leaves. Zn stress significantly reduced the growth attributes. A marked drop in all morphophysiological attributes such as root length, leaf number and shoot length was recorded. Maximum reduction of growth, biochemical and physiological parameters was noted at 40mM concentration of zinc. Zinc toxicity involve in inhibition of cytoplasmic enzymes and damage to cell structures due to oxidative stress.it alter the catalytic function of enzymes which damage the cellular membranes and inhibit root growth. Zinc stress cause maximum effect on hybrid FH674 as compared to other hybrid FH687.

Keywords: Root length; Shoot length, Zinc, Sunflower, Biochemical parameters.

Copyright @ 2020: This is an open-access article distributed under the terms of the Creative Commons Attribution license which permits unrestricted use, distribution, and reproduction in any medium for non-commercial use (NonCommercial, or CC-BY-NC) provided the original author and source are credited.

\section{INTRODUCTION}

Plants can endure high concentration of heavy metals. In minute concentration some heavy metals are vital for plants but their higher amount cause stunt growth in plants. Under stress condition reactive oxygen species (ROS) are produced. Heavy metals are injurious for membrane lipids. Plant cell contain protection mechanism to reduce the effects of ROS. The agricultural soils are affected by toxicity of heavy metals due to prolonged use of phosphate fertilizers \& industrial waste. In plants lipid peroxidation is the most toxic effect of heavy metals that causes deterioration of membrane [1].

The activeness of several enzymes, proteins and carbohydrates especially in oil crops is basically regulated by $\mathrm{Zn}$. Fertilization, manufacturing of chlorophyll, pollen task need $\mathrm{Zn}$ for maintenance. Decreased yield, flawed pollens are result of $\mathrm{Zn}$ deficiency. Restricted root growth and reduce potency of $\mathrm{Zn}$ occurs in moisture deficit conditions [2]. To lessen the tensions of drought, regulation of stomata and ion balance is maintained by fertilizer zinc sulfate which is balanced during water deficit. Chloroplast structure is substantially affected by $S$ deficit circumstance. Under water deficit conditions the quantity and quality of sunflower is raised by micronutrient application. $\mathrm{Zn}$ finger family of transcription factors and crucial part of enzymes [3].

Metal ion contamination in the environment causes hazardous effects on plant growth, yield production, and also led to physical and chemical changes. Metal toxicity can inhibit Protein activity or disrupt their structures. $30 \%$ of the world's rearing land is $\mathrm{Zn}$-deficient. Foliar applications is competent and notable for nutrient engrossment. Foliar application of minerals is realistic. The desire for advanced living pose major threat to ecosystem as it is increased with the industrial improvement. Mainly after 1950s, populated urban environment affect the health and quality of living organisms by causing serious damages to the ecosystem. Natural and human activities are contaminating the environment, they are discharging more than what the environment can handle and affect the standard of farming products. Heavy metals scathe biomolecules that results in increase of (ROS), $(\mathrm{OH})$, 
(H2O2), (O2-) that leads to oxidative stress treating organisms with some chemical, biological and physical agents results in toxicity[4].

Zinc deficiency decreases the activity of the immune system in human beings. $\mathrm{Zn}+2$ also affects animal and plant activity. Zinc deficiency also decreases the next-generation growth. Also due to the low amount of the plants that cause damages to the plant size and cause chlorosis [5].

Sunflower(Helianthus annus L.) plant is added to be one of the most edible seed crop growing in harsh climatic regions.it also have good water use efficiency. it also led to enhances the economy of the country. Moreover, sunflower has nutritional properties, and their seeds contain high oil content 35\%-48\%[6].

Sunflower (Helianthus annuus L.) has economic importance in terms of agriculture worldwide. The high level of its fatty acid (69\%) easily explains the importance of the sunflower plant. Oilseed crops play a vital role in broiler food[7,8]. They are rich in proteins and carbohydrates. During the flowering and seed filling stage at high temperature and in drought, conditions decrease the yield production. Water stress is one the most reducing factors on sunflower range from $200-900 \mathrm{~mm}$. The high temperature increase water consumption at flowering and low while vegetative. Sunflower is drought. Soil with prominent heavy metal engrossment indorses its growth. Different mechanisms of living entity are regulated by aliphatic amines. In Turkey, major oil seed crop is sunflower due to poor climatic condition no crop rotation is done. To overcome low moisture content seeds are sown in seedbeds that results in irregular germination $[9,10]$.

\section{MATERIALS AND METHODS}

Experimentation was led to assess the consequence of zinc on sunflower (Helianthus annuus) genotype FH-687 and FH-674 in University of Agriculture Faisalabad Botanical garden through the year 2019. Zinc sulphate $\left(\mathrm{ZnSO}_{4}\right)$ utilized as basic of zinc element. Three $(0 \mathrm{mM}, 20 \mathrm{mM}$ and $40 \mathrm{mM})$ levels of $\mathrm{Zn}$ were applied in research area.

\section{Seed source}

Hybrids of two sunflower versities FH 687 and FH 674 were utilized for the research work and attained by Ayub agriculture research institute.

\section{Sowing}

18 plastic pots were occupied with $8 \mathrm{~kg}$ soil. The pots used for sowing contain an underneath hole which was covered by a piece of fine cotton cloth. Before sowing, pots were irrigated with tab water. Approximately 8 seeds were sown in each pot at the depth of $2 \mathrm{~cm}$. Healthy seeds of similar size were selected for sowing. The experiment strategy was factorial completely randomized strategy with three repetitions. Afterward propagation, plant were moistened with tap water whenever required. After germination, seedlings were thinned to maintain 4 plants per pot of equal size and then applied zinc to the plants to start my experiment [12].

\section{Treatments and Source}

Simple water used to treat plants present in the University of Agriculture, Faisalabad. The salt that we want to apply to plants are taken from our Botany Department in a specific amount and make the solution in $1.5 \mathrm{~L}$ of water and apply to specific plants[13].

\section{1- Normal water or $0 \mathrm{mM}$ zinc solution}

2- $20 \mathrm{mM}$ zinc solution

3- 40mM zinc solution

\section{Germination}

8 seeds were sown in each pot on 11/3/2019 date. After 5 days seed were germinate all pots were totally germinate first 20 days simple water was applied after 20 days they were applied $\mathrm{ZnSO}_{4}$.Just one time metal applied in whole research[15]

\section{DATA COLLECTION}

Two plants from each pot were collected after applying treatment. Plants were pulled up cautiously and washed with tab water. Data for growth, physiological and bio-chemical parameters were recorded. Fresh weight noted immediately in lab then they were left in oven to study their dry weight and for further studies.

\section{Growth parameters}

Shoot length was measured by using a measuring tape and their mean values were calculated.

\section{Root length (cm)}

Root length was measured by using a measuring tape and their mean values were calculated.

\section{Shoot fresh weight (g)}

Fresh weight of shoot was determined immediately after uprooting the plants with the help of systemic weight machine and mean values were calculated.

\section{Root fresh weight (g)}

Fresh weight of root was determined immediately after uprooting the plants with the help of systemic weight machine and mean values were calculated.

\section{Shoot dry weight (g)}

Dry weight of shoot were determined after keeping the fresh samples in oven at $65 \mathrm{C}^{\circ}$ for 1 week to get constant dry weight and mean values were calculated[16]. 


\section{Root dry weight (g)}

Dry weight of root were determined after keeping the fresh samples in oven at $65 \mathrm{C}^{\circ}$ for 1 week to get constant dry weight and mean values were calculated[17].

\section{RESULTS AND DISCUSSION \\ Shoot length (cm)}

Data for shoots length of sunflower hybrids FH 687 and FH674 grown under control (T0=Water) condition and zinc sulphate $\left(\mathrm{ZnSO}_{4}\right)$ stress condition is presented below in graph. Application of zinc sulphate stress caused a significant reduction in shoot length. With increasing concentration of zinc in soil solution shoot length reduced. Maximum reduction at $40 \mathrm{mM}$ (Water+ $\mathrm{ZnSO}_{4} 40 \mathrm{mM}$ ) zinc sulphate was applied in rooting medium was observed as compared to control series.FH 687 show better growth than the hybrid FH $674[16]$.

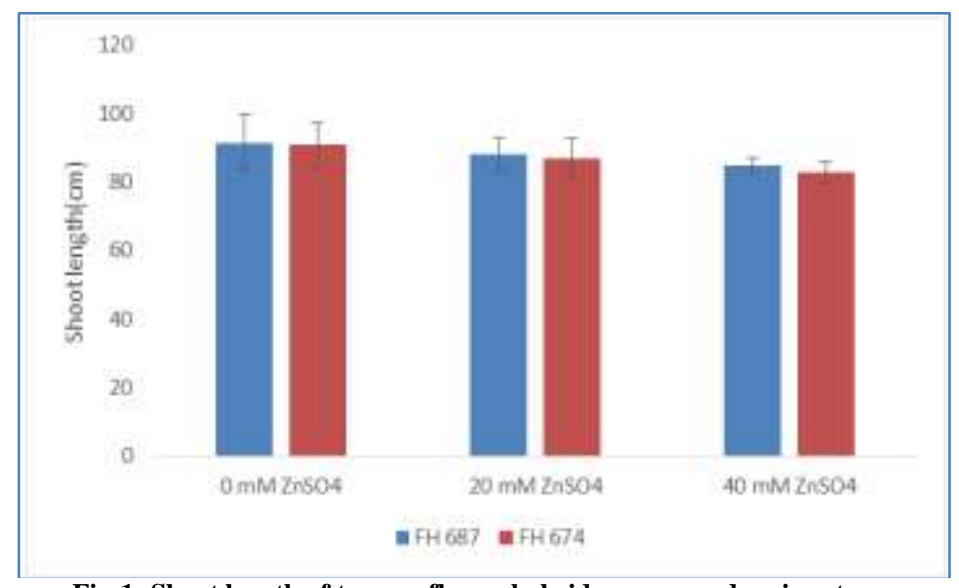

Fig-1: Shoot length of two sunflower hybrids grown under zinc stress

\section{Root length (cm)}

Data for root length of sunflower hybrids FH 687 and FH674 grown under control (T0=Water) condition and zinc sulphate $\left(\mathrm{ZnSO}_{4}\right)$ stress condition is presented below in graph. Application of zinc sulphate stress caused a significant reduction in root length. With increasing concentration of zinc in soil solution root length reduced. Maximum reduction at $40 \mathrm{mM}$ (Water $+\mathrm{ZnSO}_{4} 40 \mathrm{mM}$ ) zinc sulphate was applied in rooting medium was observed as compared to control series [17]. FH 687 show better growth than the hybrid FH 674.

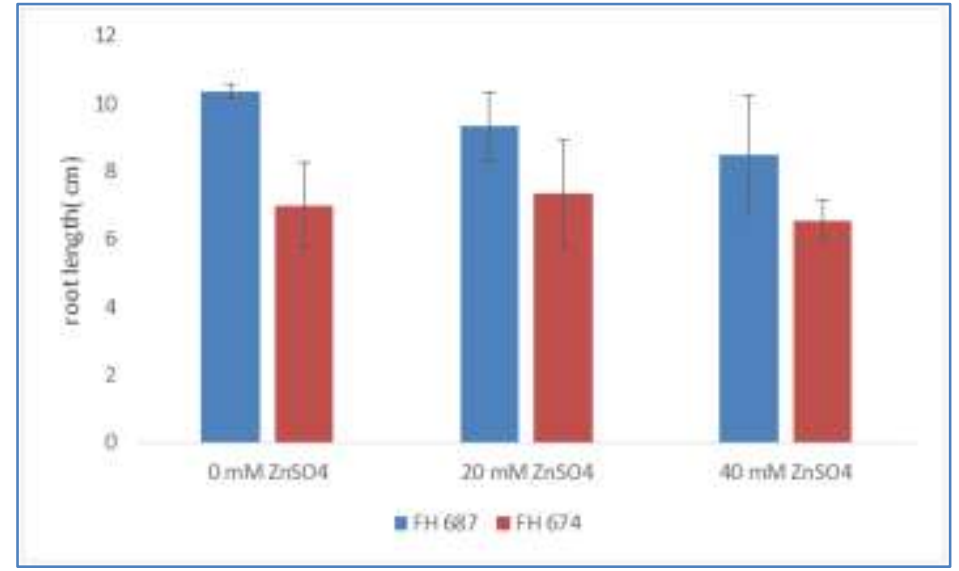

Fig-2: Root length of two sunflower hybrids grown under zinc stress

\section{Number of leaves (per plant)}

Data for number of leaves of sunflower hybrids FH 687 and FH674 grown under control (T0=Water) condition and zinc sulphate $\left(\mathrm{ZnSO}_{4}\right)$ stress condition is presented below in graph. Application of zinc sulphate stress caused a significant reduction in number of leaves. With increasing concentration of zinc in soil solution number of leaves reduced. Maximum reduction at $40 \mathrm{mM}$ (Water $+\mathrm{ZnSO}_{4} \quad 40 \mathrm{mM}$ ) zinc sulphate was applied in rooting medium was observed as compared to control series. FH 687 show better growth than the hybrid FH 674[18]. 


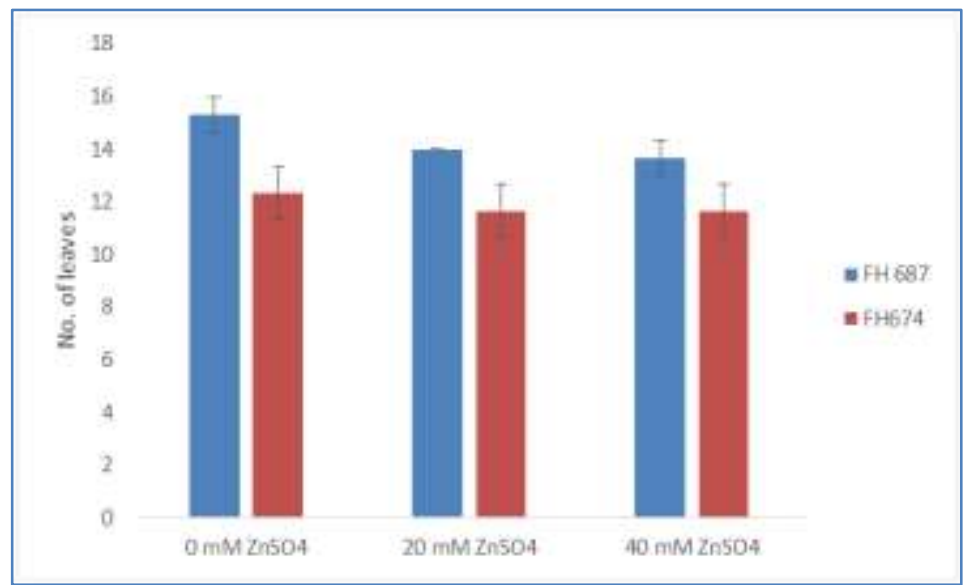

Fig-3: Number of leaves of two sunflower hybrids grown under zinc stress

\section{Root fresh weight (g)}

Data for root fresh weight of sunflower hybrids FH 687 and FH674 grown under control $(\mathrm{T} 0=$ Water $)$ condition and zinc sulphate $\left(\mathrm{ZnSO}_{4}\right)$ stress condition is presented below in graph. Application of zinc sulphate stress caused a significant reduction in root fresh weight. With increasing concentration of zinc in soil solution root fresh weight reduced. Maximum reduction at $40 \mathrm{mM}$ (Water $\left.+\mathrm{ZnSO}_{4} \quad 40 \mathrm{mM}\right)$ zinc sulphate was applied in rooting medium was observed as compared to control series.FH 687 show better growth than the hybrid FH 674.

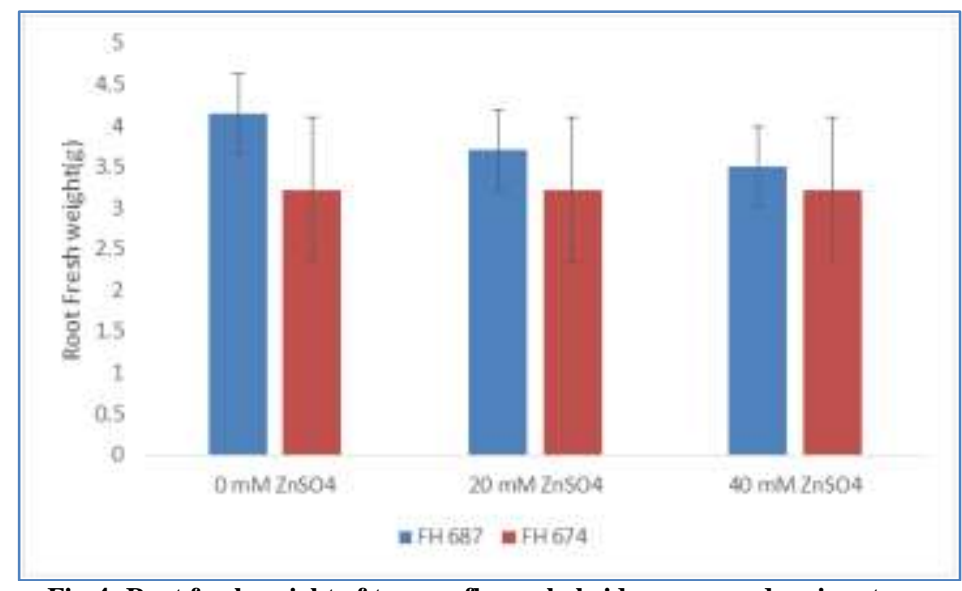

Fig-4: Root fresh weight of two sunflower hybrids grown under zinc stress

\section{Shoot fresh weight $(\mathrm{g})$}

Data for shoot fresh weight of sunflower hybrids FH 687 and FH674 grown under control (T0=Water) condition and zinc sulphate $\left(\mathrm{ZnSO}_{4}\right)$ stress condition is presented below in graph. Application of zinc sulphate stress caused a significant reduction in shoot fresh weight [18]. With increasing concentration of zinc in soil solution shoot fresh weight reduced. Maximum reduction at $40 \mathrm{mM}\left(\right.$ Water $\left.+\mathrm{ZnSO}_{4} 40 \mathrm{mM}\right)$ zinc sulphate was applied in rooting medium was observed as compared to control series. FH 687 show better growth than the hybrid FH 674[19].

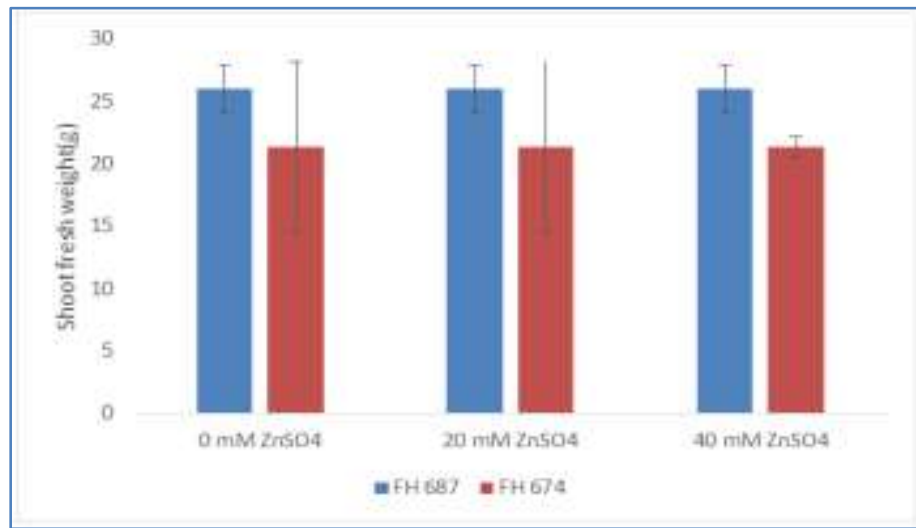

Fig-5: Shoot fresh weight of two sunflower hybrids grown under zinc stress 


\section{Root dry weight (g)}

Data for root dry weight of sunflower hybrids FH 687 and FH674 grown under control (T0=Water) condition and zinc sulphate $\left(\mathrm{ZnSO}_{4}\right)$ stress condition is presented below in graph. Application of zinc sulphate stress caused a significant reduction in root dry weight.
With increasing concentration of zinc in soil solution root dry weight reduced. Maximum reduction at $40 \mathrm{mM}$ $\left(\right.$ Water $\left.+\mathrm{ZnSO}_{4} 40 \mathrm{mM}\right)$ zinc sulphate was applied in rooting medium was observed as compared to control series. FH 687 show better growth than the hybrid FH 674.

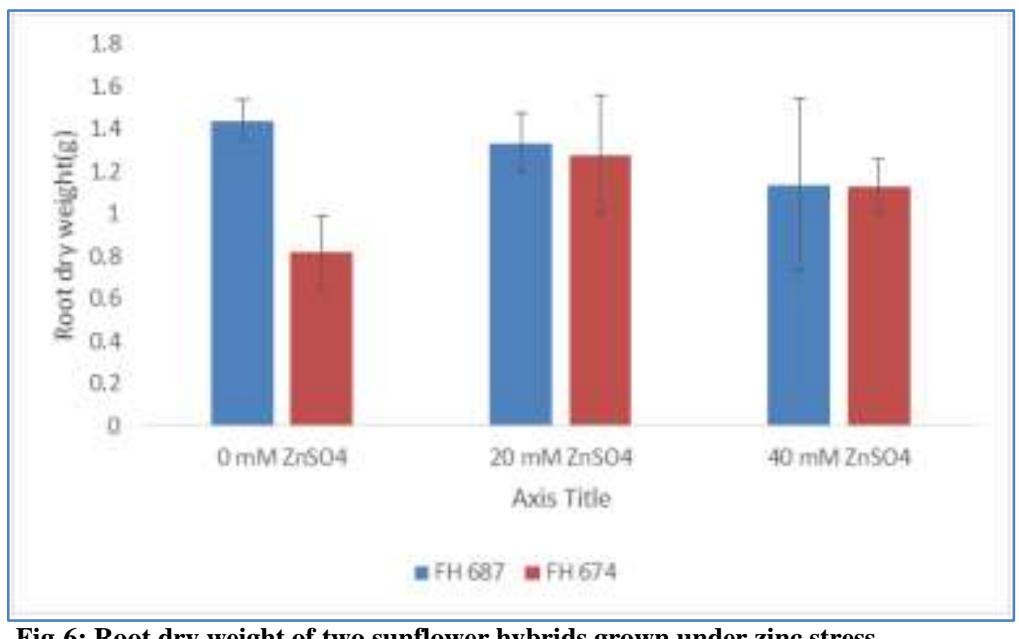

Fig-6: Root dry weight of two sunflower hybrids grown under zinc stress

\section{Shoot dry weight (g)}

Data for shoot dry weight of sunflower hybrids FH 687 and FH674 grown under control (T0=Water) condition and zinc sulphate $\left(\mathrm{ZnSO}_{4}\right)$ stress condition is presented below in graph. Application of zinc sulphate stress caused a significant reduction in shoot dry weight. With increasing concentration of zinc in soil solution shoot dry weight reduced. Maximum reduction at $40 \mathrm{mM}$ (Water $+\mathrm{ZnSO}_{4} 40 \mathrm{mM}$ ) zinc sulphate was applied in rooting medium was observed as compared to control series. FH 687 show better growth than the hybrid FH 674.

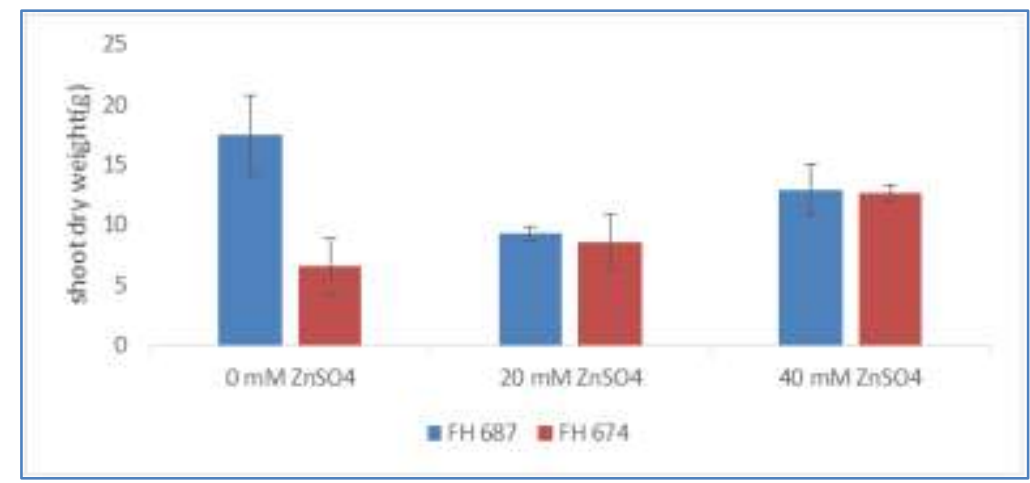

Fig-7: Shoot dry weight of two sunflower hybrids grown under zinc stress

\section{CONCLUSION}

This study helpful investigating the growth of the sunflower under the different treatments of the zinc as the metal ion contamination in the environment causes hazardous effects on plant growth, yield production, and also led to physical and chemical changes. Zinc deficiency also decreases the nextgeneration growth. Also due to the low amount of the plants that cause damages to the plant size and cause chlorosis.

\section{REFRENCES}

1. Adrees, M., Ali, S., Rizwan, M., Ibrahim, M., Abbas, F., Farid, M., \& Bharwana, S. A. (2015). The effect of excess copper on growth and physiology of important food crops: a review. Environmental Science and Pollution Research, 22(11), 8148-8162.

2. Giri, P., Kumar, R., Singh, R., \& Pandey, S. N. (2014). Effect of $\mathrm{Cu}$ application on growth, yield and biochemical responses of wheat (Triticum aestivum L.) in Gomti-upland alluvial soil.

3. Kalingan, M., Muthaiah, D., Rajagopal, S., \& Venkatachalam, R. (2015). Estimation of Barium Toxicity Mitigating Efficacy of Amaranthus caudatus L. Universal Journal of Environmental Research \& Technology, 5(6).

4. Lamichhane, J. R., Osdaghi, E., Behlau, F., Köhl, J., Jones, J. B., \& Aubertot, J. N. (2018). Thirteen decades of antimicrobial copper compounds 
applied in agriculture. A review. Agronomy for Sustainable Development, 38(3), 28.

5. Mbadra, C., Gargouri, K., Mbarek, H. B., Trabelsi, L., Arous, A., \& Chaabouni, S. E. (2019). Effect of near-road soil contamination on Solanum lycopersicum L., Cicer arietinum L. and Cucumis sativus L. International journal of environmental science and technology, 16(7), 3467-3482.

6. Van Assche, F., \& Clijsters, H. (1990). Effects of metals on enzyme activity in plants. Plant, Cell \& Environment, 13(3), 195-206.

7. Ceyhun, S. B., Şentürk, M., Yerlikaya, E., Erdoğan, O., Küfrevioğlu, Ö. İ., \& Ekinci, D. (2011). Purification and characterization of carbonic anhydrase from the teleost fish Dicentrarchus labrax (European seabass) liver and toxicological effects of metals on enzyme activity. Environmental toxicology and pharmacology, 32(1), 69-74.

8. Riordan, J. F. (1977). The role of metals in enzyme activity. Annals of Clinical \& Laboratory Science, 7(2), 119-129.

9. Kırıc1, M., Kırıc1, M., Beydemir, Ş., \& Atamanalp, M. (2016). Purification of carbonic anhydrase from Capoeta umbla (Heckel, 1843) gills and toxicological effects of some metals on enzyme activity. Turkish Journal of Fisheries and Aquatic Sciences, 16(1), 169-175.

10. Dedourge-Geffard, O., Palais, F., BiagiantiRisbourg, S., Geffard, O., \& Geffard, A. (2009). Effects of metals on feeding rate and digestive enzymes in Gammarus fossarum: an in situ experiment. Chemosphere, 77(11), 1569-1576.

11. Yang, X., Liu, J., McGrouther, K., Huang, H., Lu, K., Guo, X., \& Wang, H. (2016). Effect of biochar on the extractability of heavy metals $(\mathrm{Cd}, \mathrm{Cu}, \mathrm{Pb}$, and $\mathrm{Zn}$ ) and enzyme activity in soil. Environmental Science and Pollution Research, 23(2), 974-984.
12. Goyer, R. A., \& Clarkson, T. W. (1996). Toxic effects of metals. Casarett and Doull's toxicology: the basic science of poisons, 5, 696-8.

13. Shafiq, S., Adeel, M., Raza, H., Iqbal, R., Ahmad, Z., Naeem, M., \& Azmi, U. R. (2019). Effects of Foliar Application of Selenium in Maize (Zea Mays L.) under Cadmium Toxicity. In Biological Forum-An International Journal 11(2): 27-37.

14. Devrajani, B. R., Rahman, A. A. U., Shah, S. Z. A., \& Qureshi, G. A. (2012). Serum trace metals and enzyme activity in patients with hepatic encephalopathy. World Appl Sci J,16(8), 10531059.

15. Naeem, M., Ali, J., Hassan, M. Z., Arshad, B., Rao, M. H. I., Sarmad, M. S. K., .\&amp; Hassan, M. U. (2019). Novel Approach towards DNA Barcoding as a Tool in Molecular Biologyand Biological Activities of Cyclotides with Particular Emphasizes at Molecular Level. In Biological Forum-An InternationalJournal, 11(2): 83-96.

16. Naeem, A., Saddique, S., \&amp; Chand, S. A. (2019). Advancement and Future Directions towards Herbal Treatment for Various Diseases.

17. Ahmad, I., Khan, S., Naeem, M., Hayat, M., Azmi, U. R., Ahmed, S., \&amp; Irfan, M. (2019). Molecular Identification of Ten Palm Species using DNA Fingerprinting. Int. J. Pure App. Biosci, 7(1), 46- 51.

18. Sen, A., \& Semiz, A. (2007). Effects of metals and detergents on biotransformation and detoxification enzymes of leaping mullet (Liza saliens). Ecotoxicology and Environmental Safety, 68(3), 405-411.

19. Asadishad, B., Chahal, S., Akbari, A., Cianciarelli, V., Azodi, M., Ghoshal, S., \& Tufenkji, N. (2018). Amendment of agricultural soil with metal nanoparticles: effects on soil enzyme activity and microbial community composition. Environmental science \& technology, 52(4), 1908-1918. 